\title{
ESTIMATION OF THE POTENTIAL EVAPOTRANSPIRATION BY A SIMPLIFIED PENMAN METHOD
}

\author{
NILSON A. VILLA NOVA ${ }^{1}$, JARBAS H. DE MIRANDA ${ }^{2}$, ANDRÉ B. PEREIRA ${ }^{3}$, \\ KÉSIA O. DA SILVA ${ }^{4}$
}

\begin{abstract}
The numerous methods for calculating the potential or reference evapotranspiration (ETo or ETP) almost always do for a 24-hour period, including values of climatic parameters throughout the nocturnal period (daily averages). These results have a nil effect on transpiration, constituting the main evaporative demand process in cases of localized irrigation. The aim of the current manuscript was to come up with a model rather simplified for the calculation of diurnal daily ETo. It deals with an alternative approach based on the theoretical background of the Penman method without having to consider values of aerodynamic conductance of latent and sensible heat fluxes, as well as data of wind speed and relative humidity of the air. The comparison between the diurnal values of ETo measured in weighing lysimeters with elevated precision and estimated by either the Penman-Monteith method or the Simplified-Penman approach in study also points out a fairly consistent agreement among the potential demand calculation criteria. The SimplifiedPenman approach was a feasible alternative to estimate ETo under the local meteorological conditions of two field trials. With the availability of the input data required, such a method could be employed in other climatic regions for scheduling irrigation.
\end{abstract}

KEYWORDS: crop water use, Bowen ratio, energy balance.

\section{ESTIMATIVA DA EVAPOTRANSPIRAÇÃO POTENCIAL PELO MÉTODO DE PENMAN-SIMPLIFICADO}

RESUMO: Os inúmeros métodos existentes para o cálculo da evapotranspiração potencial (ETo), quase sempre o fazem para períodos de 24 horas, incluindo valores de parâmetros climáticos do período noturno (médias diárias), os quais têm efeito nulo na transpiração, que é a principal demanda nos casos de irrigação localizada. No presente trabalho, teve-se o objetivo de elaborar, com base no método de Penman, um modelo bastante simplificado para o cálculo da evapotranspiração diurna, que prescinde de dados de velocidade do vento e umidade relativa do ar, sem perda de precisão, ampliando bastante a sua possibilidade de aplicação. A comparação entre os valores de ETo, diários-diurnos, medidos em lisímetros de pesagem de alta precisão e os valores estimados tanto pela metodologia em estudo como pelo critério de cálculo proposto por PenmanMonteith, indicou elevada concordância entre valores observados e calculados. O método de Penman-Simplificado foi, portanto, uma alternativa viável para estimar a ETo, sob as condições meteorológicas locais de dois experimentos de campo. Com a disponibilidade dos elementos climáticos requeridos pela metodologia proposta, recomenda-se a sua aplicação em outras localidades para fins de irrigação.

PALAVRAS-CHAVE: consumo hídrico, razão de Bowen, balanço de energia.

\footnotetext{
${ }^{1}$ Prof. Associado, Departamento de Ciências Exatas, Escola Superior de Agricultura "Luiz de Queiroz" - ESALQ/USP, Av. Pádua Dias, 11, Piracicaba - SP, Fone: (0XX19) 3429.4283 ramal: 224, Pesquisador CNPq, navnova@esalq.usp.br

${ }^{2}$ Prof. Dr., Departamento de Ciências Exatas, ESALQ/USP, jhmirand@esalq.usp.br

${ }^{3}$ Prof. Dr., Departamento de Ciência do Solo e Engenharia Agrícola, Universidade Estadual de Ponta Grossa, UEPG, Setor de Ciências Agrárias e de Tecnologia, abelmont@uepg.br

${ }^{4}$ Prof $^{\text {a }}$. Dr ${ }^{\mathrm{a}}$., Departamento de Engenharia Rural, ESALQ/USP, kosilva@esalq.usp.br

Recebido pelo Conselho Editorial em: 13-12-2005
}

Aprovado pelo Conselho Editorial em: 9-10-2006 


\section{INTRODUCTION}

The estimate of water consumption by the crops plays a crucial role on the agricultural planning, mainly for irrigation scheduling assuring maximum yields and better quality with environmental protection. Therefore, in order to predict either when to initiate irrigation or how much water to apply throughout a complete crop growing cycle, crop evapotranspiration (ETc) is expected to be determined at a given site. THORNTHWAITE \& HOLZMAN (1944) defined potential or reference evapotranspiration (ETo) as the water used by a uniform, actively growing, full-cover grass sward (Paspalum notatum L.) or alfalfa (Medicago sativa L.) canopy with an unrestricted water supply grown at an area sufficiently large to minimize the oasis effect.

Thus, with regard to the values of the aforementioned environmental variable, BERNARDO (1995) reports that reference evapotranspiration (ETo) might be obtained by both direct and indirect estimation methods. Direct methods are those that make use of lysimeters and provide the highest accuracy for its determination, require installation of experimental plots in the field, control of soil moisture and a methodological procedure to assess the input and output of water in large areas.

However, according to MENDONÇA et al. (2003), such methods due to its high costs have their use restricted to research institutions and are usually utilized for regional calibration of indirect methods.

A simplified estimation method to calculate the potential evapotranspiration was developed based on the Penman approach, considering only the diurnal values of evapotranspiration rates that are more representative of the water vapor transfer process to the atmosphere for a given agricultural ecosystem. In addition, the classical expression of the Bowen ratio $(\beta)$ was modified herein by considering the sensible heat flux $(\mathrm{H})$ emergent from the evaporative surface in conjunction with the air turbulent flux, which transports also latent heat flux (LE). Such procedure results in a similarity between the aerodynamic resistances of sensible heat and latent heat fluxes so as to allow for a considerable simplification without impairing the estimates, as conspicuously shown by the results present in this paper.

\section{MATERIAL AND METHODS}

The present work was developed in Piracicaba, State of São Paulo, Brazil (22 $42^{\prime} 30^{\prime}$ 'S, longitude of $47^{\circ} 30^{\prime} 00^{\prime} ' \mathrm{~W}$, and altitude of $576 \mathrm{~m}$ ) using diurnal daily mean meteorological data, collected from experiments carried out by MAGGIOTTO (1996) and PEREIRA (1998). The input data were: air temperature $\left({ }^{\circ} \mathrm{C}\right)$, relative humidity $(\%)$, wind speed at two meters high $\left(\mathrm{m} \mathrm{s}^{-1}\right)$, net radiation $\left(\mathrm{MJ} \mathrm{m}^{-2} \mathrm{day}^{-1}\right)$, soil sensible heat flux $\left(\mathrm{MJ} \mathrm{m}^{-2}\right.$ day $\left.^{-1}\right)$.

For the proposed method in this study, it was assumed that on any vegetated surface the leaves receiving short wave radiation density flux (exposed directly to the sun), as long as water restrictions never occur, will be subjected to the following conditions in compliance with net radiation $(\mathrm{Rn})$, which can be also determined by estimate equations proposed by PEREIRA et al. (1998), during the diurnal period (considering leaf temperature roughly equal to air temperature):

a) Before receiving short wave radiation density flux (foliar surface in the shade)

a.1) $\mathrm{Rn}=0$

a.2) Leaf temperature approximately equal to wet bulb temperature $\left(T_{c} \cong T^{\prime}\right)$

a.3) Air temperature (Ta)

b) Receiving short wave irradiance

Aiming at proposing an equation for calculating the potential evapotranspiration (E) PENMAN (1948) adopted the concept denominated Bowen ratio ( $\beta$ ) (BOWEN, 1926), taking into consideration air sensible heat $(\mathrm{H})$, latent heat $(\lambda \mathrm{E})$ and soil sensible heat $(\mathrm{G})$ fluxes from the net 
radiation $(\mathrm{Rn})$ over a vegetated surface with no water supply restrictions. Considering that the eventual energy storages $(\mathrm{S})$ are negligible one may write:

$$
(\mathrm{Rn}-\mathrm{G})=\lambda \mathrm{E}+\mathrm{H}
$$

BOWEN (1926) nominated Bowen ratio $(\beta)$ the relation:

$$
\beta=\frac{H}{\lambda E}
$$

Thus, substituting (2) in (1) results in:

$$
(\mathrm{Rn}-\mathrm{G})=\lambda \mathrm{E}(1+\beta)
$$

With the incidence of Rn over the leaf and assuming that its temperature corresponding to T' equal to Ta, and given to the fact that sensible heat gains due to storage variations regarding the turbulent fluxes of latent heat $(\mathrm{LE})$ and sensible heat $(\mathrm{H})$ are negligible, LE and $\mathrm{H}$ might be expressed by the following equations:

$$
\begin{aligned}
& \mathrm{LE}=\rho \frac{0.622(\mathrm{es}-\mathrm{e})}{\mathrm{P}} \lambda \mathrm{CV} \\
& \mathrm{H}=\rho \mathrm{Cp}\left(\mathrm{Ta}-\mathrm{T}^{\prime}\right) \mathrm{Ca}
\end{aligned}
$$

Where:

$\mathrm{LE}$ - latent heat flux $\left(\mathrm{MJ} \mathrm{m}^{-2} \mathrm{~s}^{-1}\right)$;

$(\mathrm{es}-\mathrm{e})$ - deficit of air saturation vapor pressure $(\mathrm{kPa})$;

$\mathrm{P}$ - local atmospheric pressure $(\mathrm{kPa})$;

$\rho$ - wet air density $\left(\mathrm{kg} \mathrm{m}^{-3}\right)$;

$\mathrm{Cv}$ - aerodynamic conductance of water vapor turbulent transport $\left(\mathrm{m} \mathrm{s}^{-1}\right)$;

$\lambda$ - latent heat of vaporization $\left(2.45 \mathrm{MJ} \mathrm{kg}^{-1}\right)$;

$\mathrm{H}$ - sensible heat flux $\left(\mathrm{MJ} \mathrm{m}^{-2} \mathrm{~s}^{-1}\right)$;

$\mathrm{Cp}$ - wet air specific heat $\left(\mathrm{MJ} \mathrm{kg}^{-1}{ }^{\mathrm{o}} \mathrm{C}^{-1}\right)$, and

$\mathrm{Ca}$ - aerodynamic conductance of sensible heat turbulent transport $\left(\mathrm{m} \mathrm{s}^{-1}\right)$.

To define $\beta$ in the proposed model it was assumed that for a well-watered leaf, $\lambda \mathrm{E}$ and $\mathrm{H}$ are equally conditioned by the turbulent transport of wet air as a function of the temperature difference $\left(\mathrm{Ta}-\mathrm{T}^{\prime}\right)$ and deficit of air saturation pressure (es - e). By replacing 4 and 5 into 2, the similarity between both leaf and air aerodynamic resistances $\left(\mathrm{ra}_{\mathrm{v}}\right.$ and $\left.\mathrm{ra}_{\mathrm{H}}\right)$ allows the proposition of the following modified $\beta$ ratio:

$$
\beta=\frac{H}{\lambda E}=\frac{\rho \mathrm{Cp}\left(\mathrm{Ta}-\mathrm{T}^{\prime}\right) \mathrm{Ca}}{\rho \frac{0.622(\mathrm{es}-\mathrm{e}) \mathrm{Cv} \lambda}{\mathrm{P}}}
$$

By supposing $\mathrm{Ca} \cong \mathrm{Cv}$ and computing the psychometric coefficient $(\gamma)$ using:

$$
\gamma=\frac{\mathrm{Cp} \mathrm{P}}{0.622 \lambda}
$$

and substituting 7 into 6 , one will have:

$$
\beta=\frac{\mathrm{H}}{\lambda \mathrm{E}}=\frac{\gamma\left(\mathrm{Ta}-\mathrm{T}^{\prime}\right)}{(\mathrm{es}-\mathrm{e})}
$$

By considering now the classical psychometric equation defined by:

$$
\mathrm{e}=\mathrm{es}^{\prime}-\gamma\left(\mathrm{Ta}-\mathrm{T}^{\prime}\right)
$$


where:

e - actual vapor pressure of the atmospheric air $(\mathrm{kPa})$, and

es' - saturation vapor pressure at wet bulb temperature $(\mathrm{kPa})$.

And replacing 9 into 8 and canceling out the identical terms one will obtain:

$$
\beta=\frac{\gamma\left(\mathrm{Ta}-\mathrm{T}^{\prime}\right)}{\mathrm{es}_{(\mathrm{T})}-\mathrm{es}^{\prime}+\gamma\left(\mathrm{Ta}-\mathrm{T}^{\prime}\right)}=\frac{1}{\frac{\left(\mathrm{es}-\mathrm{es}^{\prime}\right)}{\gamma\left(\mathrm{Ta}-\mathrm{T}^{\prime}\right)}+1}
$$

As recommended by PENMAN (1948), the value of S, corresponding to the tangent to water vapor saturation pressure (es) curve at the point of daily mean air temperature, is given by the following expression:

$$
\mathrm{S}=\frac{(\mathrm{es}-\mathrm{es})}{\left(\mathrm{Ta}-\mathrm{T}^{\prime}\right)}
$$

By substituting 11 in 10 one will have:

$$
\beta=\frac{1}{\frac{S}{\gamma}+1}=\frac{\gamma}{S+\gamma}
$$

PENMAN (1948) defined the adjustment factor of the net radiation $(\omega)$ as follows:

$$
\omega=\frac{S}{S+\gamma}
$$

With $\frac{\gamma}{S+\gamma}=1-\omega$ which replaced into 12 results in a new concept for $\beta$, defined as:

$\beta=1-\omega$ will have:

By substituting 14 into 3 and considering the latent heat of vaporization $\lambda=2.45 \mathrm{MJ} \mathrm{kg}^{-1}$ one

$$
E=\frac{(R n-G)}{\lambda(2-\omega)}
$$

Needless to mention that during the evaporation or transpiration, as well as evapotranspiration processes throughout the entire diurnal period, the diurnal mean values of Ta were considered to define $\omega$, which might be seen in Table 1 for different local altitudes.

Thus, given $\lambda=2.45 \mathrm{MJ} \mathrm{kg}^{-1}$ and by substituting it into15, E will be given by:

$$
\mathrm{E}=0.408 \frac{(\mathrm{Rn}-\mathrm{G})}{(2-\omega)}
$$

where:

E - evapotranspiration from the wet surface $\left(\mathrm{mm} \mathrm{day}^{-1}\right)$ during the sunshine period;

$\mathrm{G}$ - heat flux in the soil ( $\mathrm{MJ} \mathrm{m}^{-2}$ day $^{-1}$ ) during the diurnal period;

$\mathrm{Rn}$ - diurnal net radiation at a vegetated surface $\left(\mathrm{MJ} \mathrm{m}^{-2} \mathrm{day}^{-1}\right)$, and

$\omega$ - tangent of water the vapor saturation pressure curve at the point of diurnal daily mean air temperature $(\mathrm{Ta})$. 
TABLE 1 . Values of $\omega$ as a function of the diurnal mean temperature $\left({ }^{\circ} \mathrm{C}\right)$ and altitude $(\mathrm{m})$.

\begin{tabular}{cccccc}
\hline Temperature/Altitude & 0 & 500 & 1000 & 2000 & 3000 \\
\hline 2 & 0.43 & 0.45 & 0.46 & 0.49 & 0.52 \\
\hline 4 & 0.46 & 0.48 & 0.49 & 0.52 & 0.55 \\
\hline 6 & 0.49 & 0.51 & 0.52 & 0.55 & 0.58 \\
\hline 10 & 0.52 & 0.54 & 0.55 & 0.58 & 0.61 \\
\hline 12 & 0.55 & 0.57 & 0.58 & 0.61 & 0.64 \\
\hline 14 & 0.58 & 0.60 & 0.61 & 0.64 & 0.66 \\
\hline 16 & 0.61 & 0.20 & 0.64 & 0.66 & 0.69 \\
\hline 18 & 0.64 & 0.65 & 0.66 & 0.69 & 0.71 \\
\hline 20 & 0.66 & 0.67 & 0.69 & 0.71 & 0.73 \\
\hline 22 & 0.69 & 0.70 & 0.71 & 0.73 & 0.75 \\
\hline 24 & 0.71 & 0.72 & 0.73 & 0.75 & 0.77 \\
\hline 26 & 0.73 & 0.74 & 0.75 & 0.77 & 0.79 \\
\hline 28 & 0.75 & 0.76 & 0.77 & 0.79 & 0.81 \\
\hline 30 & 0.77 & 0.78 & 0.79 & 0.81 & 0.82 \\
\hline 32 & 0.78 & 0.79 & 0.80 & 0.82 & 0.84 \\
\hline 34 & 0.80 & 0.81 & 0.82 & 0.84 & 0.85 \\
\hline 36 & 0.82 & 0.82 & 0.83 & 0.85 & 0.86 \\
\hline 38 & 0.83 & 0.84 & 0.85 & 0.86 & 0.88 \\
\hline 40 & 0.84 & 0.85 & 0.86 & 0.87 & 0.88 \\
\hline & 0.85 & 0.86 & 0.87 & 0.88 & 0.89 \\
\hline
\end{tabular}

Equation 16 depicts a new way of using the radiant energy balance for estimation of evaporation or transpiration of systems that behave in accordance with conditions established here (presence of sensible and latent heat turbulent fluxes at surfaces not subjected to water stress). The described method will from now be referred to as the Simplified-Penman approach and will always be applied to surfaces throughout the periods in which $\mathrm{Rn}$ is positive and greater than zero.

\section{RESULTS AND DISCUSSION}

The diurnal values of meteorological data concerning the experiment conducted by MAGGIOTTO (1996) and PEREIRA (1998), as well those of potential evapotranspiration (ETo) estimated by the Penman-Monteith method and measured by weighing lysimeters with high accurate load cells were used to plot the graphs shown in Figures 1 and 2, respectively.

The statistical analysis based on a linear regression study applied to observed and calculated ETo rates, reveals the feasibility of the proposed methodology for the site in study, whose accuracy is confirmed by high coefficients of determination (greater than 0.92) and also by an extremely small dispersion of the data around the fitted 1:1 line (Figure 1). When comparing both methods, the proposed approach against Penman method and lysimetric measurements it was possible to observe that the standard errors were, respectively, $0.247 \mathrm{~mm} \mathrm{day}^{-1}$ and $0.4367 \mathrm{~mm} \mathrm{day}^{-1}$. Another set of data collected by PEREIRA (1998) was used to reinforce the excellency of the SimplifiedPenman approach for the same site.

The comparison between the diurnal daily values of ETo measured in high accurate weighting lysimeters and estimated by both Penman-Monteith method and by the SimplifiedPenman approach also points out a fairly consistent agreement with the potential demand calculation criteria - a fact that can be statistically confirmed by coefficients of determination greater than 0.88, as well as by a small dispersion of the data around the 45 degree line (Figure 2).

The Simplified-Penman approach produced a satisfactory performance at the site where these field trials were conducted, with a high degree of accuracy for estimating daytime potential evapotranspiration (under conditions of Rn positive and different from zero). The coefficients of 
determination and correlation indicate the degree of accuracy but do not reveal the precision of the model (PEREIRA et al., 2003). It is possible to verify by means of the Figures 1 and 2 that both accuracy, given by the trend line, and precision demonstrated by the dispersion of the data around the fitted 1:1 line, were excellent in this study.

All the theoretical background involved in the Penman-Monteith method to calculate ETo is well established and, therefore, the method could be used with a satellite-linked network of automated agricultural weather stations to provide information for irrigation scheduling at the farmer level.

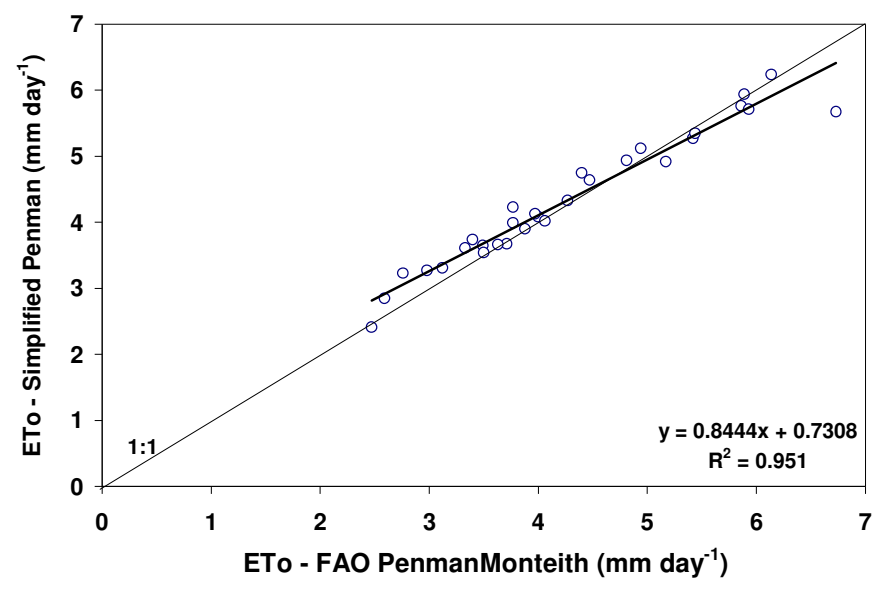

(A)

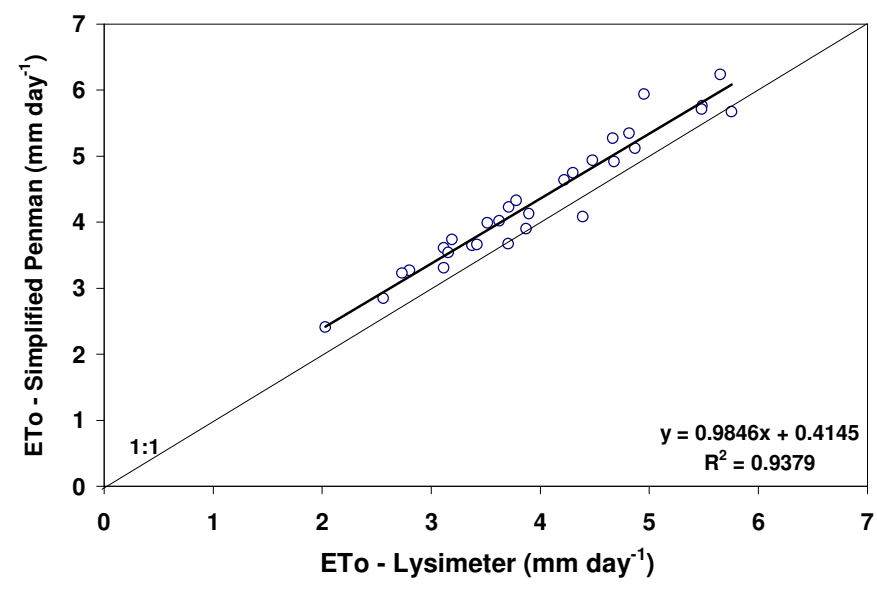

(B)

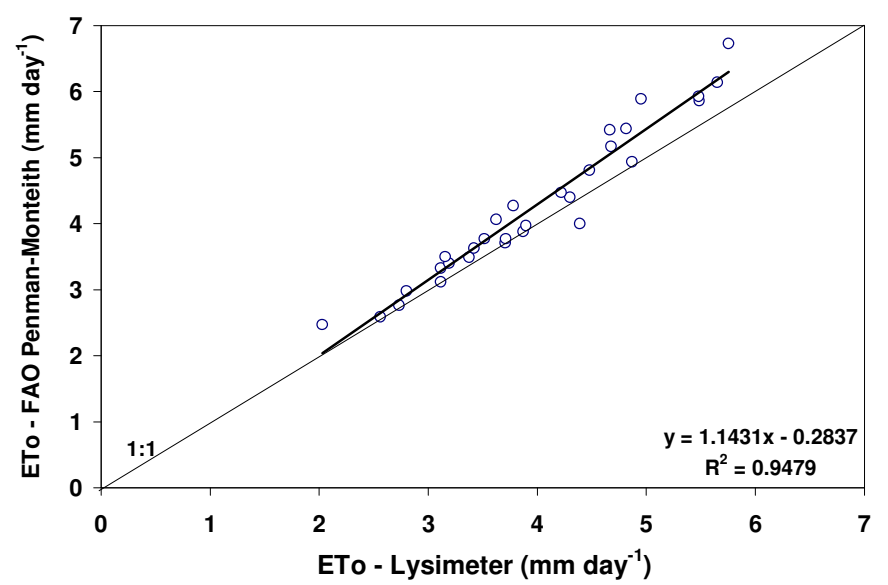

(C)

FIGURE 1. Comparison between potential evapotranspiration rates estimated by the SimplifiedPenman approach and the FAO Penman-Monteith method (A) and measured by weighing lysimeters with load cells (B), as well as between estimates obtained by the FAO Penman-Monteith method and lysimetric measurements (C). Experimental data collected by MAGGIOTTO (1996) at Piracicaba - SP, Brazil. 


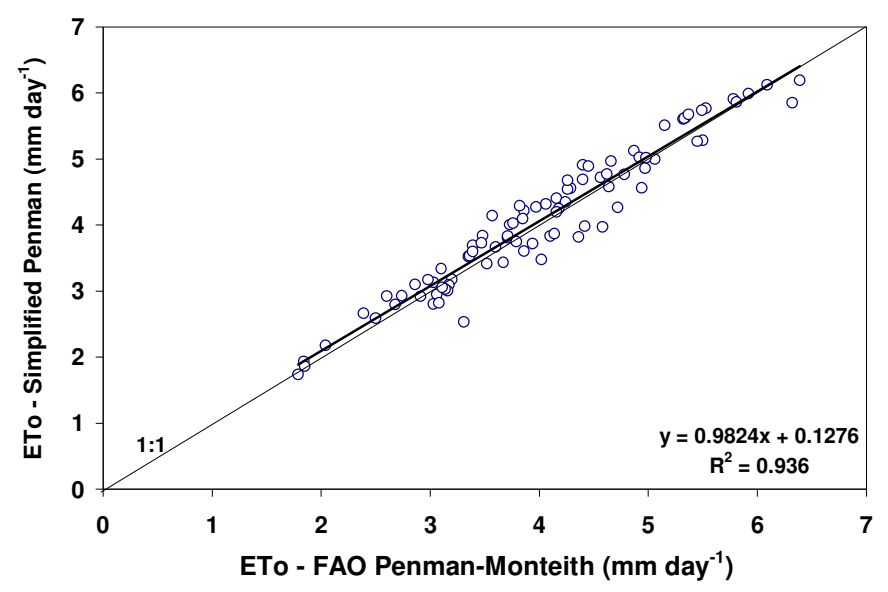

(A)

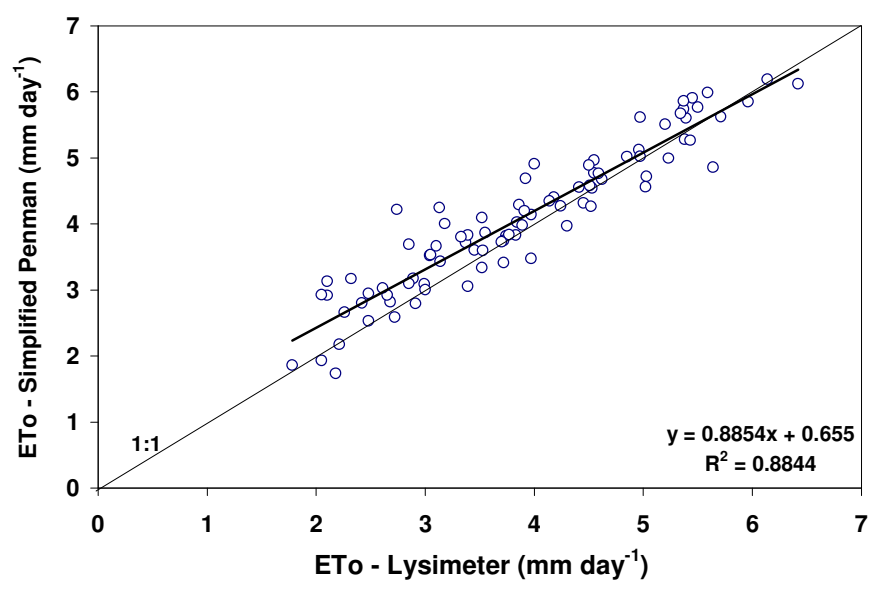

(B)

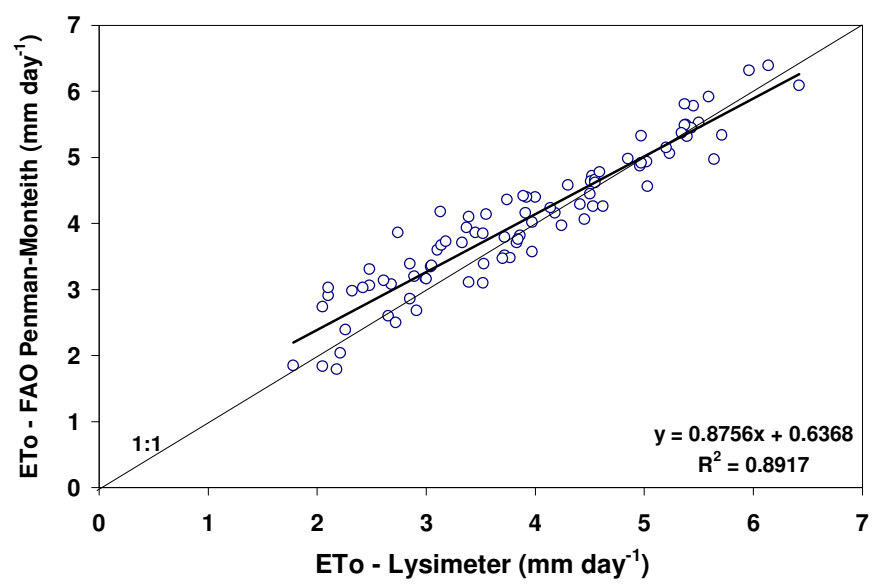

(C)

FIGURE 2. Comparison between potential evapotranspiration rates estimated by the SimplifiedPenman approach and the FAO Penman-Monteith method (A) and measured by weighing lysimeters with load cells (B), as well as between estimates obtained by the FAO Penman-Monteith method and lysimetric measurements (C). Experimental data collected by PEREIRA (1998) at Piracicaba - SP, Brazil.

Its limitation in practical terms is, however, related to a large number of environmental variables that are necessary to determine ETo either by the Penman-Monteith method or the classical Bowen ratio-energy balance approach. Furthermore, the lack of automatic weather station systems available to monitor the atmospheric parameters in many developing countries justifies the use of alternative methods for determining ETo as a function of fewer measured parameters. Mainly if the result has a precision comparable to standard methods, such as lysimetric measurements or Penman-Monteith estimates (PEREIRA et al., 2004). 
Further investigations should be carried out to examine the performance of the SimplifiedPenman approach at other sites, particularly those under very dry conditions, where the sustainability of agriculture with environmental protection will only be possible with irrigation and under considerable advection of energy in wet regions.

\section{CONCLUSIONS}

The Simplified-Penman approach as a feasible alternative to evaluate standard reference evapotranspiration. Under the local meteorological conditions of two field experiments conducted at the same site, the proposed method produced estimates accurate to those obtained by the classical Penman-Monteith method. In addition, the Simplified-Penman approach had the added advantage of simplifying ETo calculation.

When compared to potential demand measurements obtained with weighting lysimeters, the Simplified-Penman approach showed a high statistical accuracy and precision, expressed by coefficients of determination greater than 0.92 and by an extremely small dispersion of the data around the $45^{\circ}$ line. Therefore, given the availability of the input data required, it could be employed in other climatic regions to provide evapotranspiration estimates for irrigation scheduling.

\section{ACKNOWLEDGEMENTS}

To the Conselho Nacional de Desenvolvimento Científico e Tecnológico (CNPq-Brazil) for the financial support provided.

\section{REFERENCES}

BERNARDO, S. Manual de irrigação. 6. ed. Viçosa-MG: Universidade Federal de Viçosa, 1995. $657 \mathrm{p}$.

BOWEN, I.S. The ratio of heat losses by conductions and by evaporation from any water surface. Physical Review, New York, v.27, p.779-87, 1926.

MAGGIOTTO, S.R. Estimativa da evapotranspiração de referência pelo uso da termometria ao infravermelho. 1996, 71f. Dissertação (Mestrado em Irrigação e Drenagem) - Escola Superior de Agricultura “Luiz de Queiroz”, Universidade de São Paulo, Piracicaba, 1996.

MENDONÇA, J.C.; SOUSA, E.F.; BERNARDO, S.; DIAS, G. P.; GRIPPA, S. Comparação entre métodos de estimativa da evapotranspiração de referência (ETo) na região Norte Fluminense, RJ. Revista Brasileira de Engenharia Agrícola e Ambiental, Campina Grande, v.7, p.275-9, 2003.

PENMAN, H.L. Natural evaporation from open water, bare soil and grass. Proceedings of Royal Society of London, London, v.193, p.120-45, 1948.

PEREIRA, F.A.C. Desempenho do modelo de Penman-Monteith e de dois evapotranspirômetros na estimativa da evapotranspiração de referência (ETo) em relação a um lisímetro de pesagem. 1998. 87 f. Tese (Doutorado em Irrigação e Drenagem) - Escola Superior de Agricultura "Luiz de Queiroz”, Universidade de São Paulo, Piracicaba, 1998.

PEREIRA, A.B.; SENTELHAS, P.C.; VILLA NOVA, N.A. Estimativa do balanço de energia radiante em função de elementos climáticos. Revista Brasileira de Agrometeorologia, Santa Maria, v.6, n.2, p.201-6, 1998.

PEREIRA, A.B.; VILLA NOVA, N.A.; GALVANI, E. The estimation of global solar radiation flux density in Brazil from a single measurement at solar noon. Biosystems Engineering, London, v.86, n.1, p.27-34, 2003. 
PEREIRA, A.B.; VILLA NOVA, N.A.; SHOCK, C.C. Estimation of reference evapotranspiration by a modified Bowen method. In: ANNUAL INTERNATIONAL IRRIGATION SHOW - THE IRRIGATION ASSOCIATION, 25., 2004, Tampa Bay, Florida. Proceedings... p.325-39.

THORNTHWAITE, W.C.; HOLZMAN, B. Measurement of evaporation from land and water surface. Washington: U.S. Department of Agriculture, 1944. p. 4-11 (Technical Bulletin, 817-B). 